\title{
Comparing effects of nutrients on algal biomass in streams in two regions with different disturbance regimes and with applications for developing nutrient criteria
}

\author{
R. Jan Stevenson ${ }^{1, *}$, Steven T. Rier ${ }^{2}$, Catherine M. Riseng ${ }^{3}$, Richard E. Schultz ${ }^{4}$ \\ \& Michael J. Wiley ${ }^{3}$ \\ ${ }^{1}$ Department of Zoology, Michigan State University, East Lansing, MI, 48824, USA \\ ${ }^{2}$ Department of Biological \& Allied Health Sciences, Bloomsburg University, Bloomsburg, PA, 17815, USA \\ ${ }^{3}$ School of Natural Resources and the Environment, The University of Michigan, Ann Arbor, MI, 48109, USA \\ ${ }^{4}$ Department of Biological Sciences, University of Louisville, Louisville, KY, 40292, USA \\ (*Author for correspondence: E-mail: rjstev@msu.edu)
}

Key words: algae, benthic, nutrients, streams, regions, biomass

\begin{abstract}
Responses of stream algal biomass to nutrient enrichment were studied in two regions where differences in hydrologic variability cause great differences in herbivory. Around northwestern Kentucky (KY) hydrologic variability constrains invertebrate biomass and their effects on algae, but hydrologic stability in Michigan (MI) streams permits accrual of high herbivore densities and herbivory of benthic algae. Multiple indicators of algal biomass and nutrient availability were measured in 104 streams with repeated sampling at each site over a 2 -month period. Many measures of algal biomass and nutrient availability were positively correlated in both regions, however the amount of variation explained varied with measures of biomass and nutrient concentration and with region. Indicators of diatom biomass were higher in KY than MI, but were not related to nutrient concentrations in either region. Chl $a$ and \% area of substratum covered by Cladophora were positively correlated to nutrient concentrations in both regions. Cladophora responded significantly more to nutrients in MI than KY. Total phosphorus (TP) and total nitrogen (TN) explained similar amounts of variation in algal biomass, and not significantly more variation in biomass than dissolved nutrient concentrations. Low N:P ratios in the benthic algae indicated $\mathrm{N}$ as well as $\mathrm{P}$ may be limiting their accrual. Most observed responses in benthic algal biomass occurred in nutrient concentrations between 10 and $30 \mu \mathrm{g} \mathrm{TP} 1^{-1}$ and between 400 and $1000 \mu \mathrm{g} \mathrm{TN}{ }^{-1}$.
\end{abstract}

\section{Introduction}

Problems with high algal biomass due to nutrient enrichment in streams and other habitats has been the subject of considerable concern (Carpenter et al., 1998; Smith et al., 1999) and have lead to efforts by the US Environmental Protection Agency to develop nutrient criteria that prevent nuisance growths of algae (USEPA, 1999). Many studies have documented effects of nutrients on algae (Bourassa \& Cattaneo, 1998; Dodds et al., 1998; Biggs, 2000), but relationships in regional studies are seldom precise or accurate enough to predict benefits of specific nutrient regulations for streams throughout a region. In addition, many factors could affect algal-nutrient relationships in streams within a region and among regions with different climate, geology, water chemistry, 
and hydrology (Biggs et al., 1990, 1998; Stevenson, 1997b). Understanding differences in algalnutrient relationships between very different regions would help establish the range of possibilities that can be expected and the factors that regulate that range.

Disturbance regime has been hypothesized to be a major factor regulating between-region differences in algal-nutrient relationships in streams. High current velocities associated with elevated discharge following rains scour algae directly or indirectly by tumbling substrata (Power \& Stewart, 1987; Biggs \& Thomsen, 1995). Disturbance regimes with low intensity or high predictability (Poff \& Ward, 1989) support development of high grazer densities that constrain algal growths (Wootton et al., 1996; Riseng et al., 2004). Alternatively, high intensity and frequency disturbance regimes could constrain algal growth (Biggs, 1995; Clausen \& Biggs, 1997). Shading and regional factors such as water chemistry and temperature may also affect the ability of large growths to occur by limiting photosynthesis or colonization of sites by species capable of producing nuisance growths.

Lack of precision in relationships between algal biomass and nutrient concentrations may also be due to variability in estimates of algal biomass and nutrient concentrations in streams. Algal biomass varies greatly during colonization after storm disturbances (Fisher et al., 1982). Patchy growths of macroalgae throughout a reach and even a riffle make assessment of algal biomass difficult when sampling. The phyla and growth forms of algae (i.e., functional group) vary seasonally from diatoms to filamentous green and blue-green algae (Blum, 1957; Hynes, 1970). Each functional group has the potential to develop very different biomasses. Nutrient concentrations vary: diurnally with microbial metabolism; daily with weatherrelated hydrologic factors and with increasing biomass and nutrient uptake during periphyton community development after storms; and seasonally with human activities and metabolism of terrestrial vegetation in watersheds (Meyer et al., 1988; Kim et al., 1992). A sampling approach with extensive and repeated sampling during the period of algal community development should reduce error variance in algal-nutrient relationships by accounting for spatial and temporal variability in nutrient concentrations.

The objectives of this study were to relate benthic and suspended algal biomass to nutrient concentrations in streams of two regions with very different disturbance regimes and where very different relationships were expected. We expected that algal-nutrient relationships would vary with type of algae, the nutrient parameter, and the region studied such that more precise relationships could be quantified if these factors were accounted for. Changes in algal biomass along nutrient gradients were studied for thresholds and additional justification for establishing nutrient criteria to prevent nuisance growths of benthic algae.

\section{Methods}

\section{Field methods}

Benthic algal biomass was assessed in 104 streams in two regions of the north-central region in the United States (Fig. 1). These regions were chosen because of observed differences in grazing effects on benthic algae that have been related to disturbance regimes in the streams (Riseng et al., 2004). Benthic invertebrate biomass was significantly lower in streams of the Kentucky-Indiana region (KY) than Michigan (MI) (Riseng et al., 2004), $t$-test, $p<0.001)$. Biomass of invertebrates was usually less than $2 \mathrm{~g} \mathrm{~m}^{-2}$ in the $\mathrm{KY}$ and greater than $3 \mathrm{~g} \mathrm{~m}^{-2}$ in MI. Invertebrates assemblages were dominated by mayflies in the KY region and by caddisflies in MI.

The KY region included 46 streams of the unglaciated Knobs region of northwestern Kentucky and southeastern Indiana, which is typified by rapid runoff due to steep topography and the underlying limestone bedrock (Burroughs, 1926; McGrain, 1983). Fifty-eight streams were located in the glaciated region of Michigan's Lower Peninsula (MI region), where precipitation slowly percolates to the groundwater and thereby, contributes to stable, consistent discharge rates (Wiley et al., 1997). Streams were chosen to represent a wide range of nutrient conditions, which were predicted based on land use/land cover types. Land use/land cover ranged from relatively pristine 


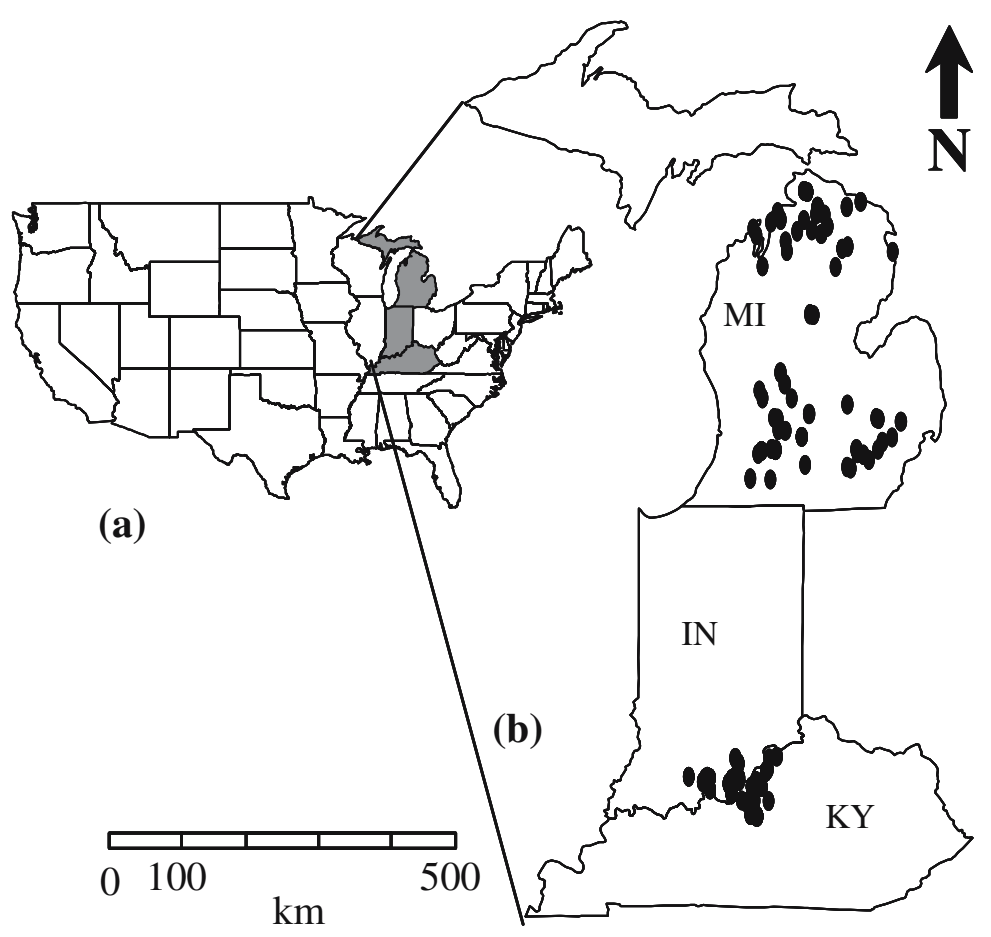

Figure 1. Location of streams sampled in northwestern Kentucky (KY) and southeastern Indiana (IN) and in Michigan (MI, USA).

forested and wetland areas to urban streams. Most stream sites flowed through a mixture of agricultural and forested land. Stream size ranged from 1st to 4th order (Strahler, 1952) with most streams being 2 nd and 3 rd order.

Sampling was conducted during 2-month sampling periods for each stream, May and June in KY and July and August in MI, during both 1996 and 1997. The sampling periods were chosen to control for temporal differences in water temperature, stream flow, and observed periods of Cladophora growth caused by latitudinal and hydrologic differences between the regions. Flow and Cladophora blooms were commonly gone in many KY streams by early summer. We restricted our sampling to riffles to minimize habitat variation among study sites and to concentrate on areas where nuisance algal proliferations tend to be greatest.

We conducted 145 assessments of algal biomass, nutrient concentrations, and habitat features in 104 streams, with 74 assessments in 1996 and 71 in 1997. Forty-one of the stream sites sampled in 1996 were re-sampled in 1997 because of the limited number of sites in the regions targeted. Eight pairs of sites (four from each region) were from the same stream in a watershed, but the lower sites were always at least 5 river kilometers downstream of the upper site. We assumed all 145 assessments were independent because flood flows in the same stream among years are commonly assumed to be independent for hydrologic and population time-series analysis in rivers (Cobb et al., 1992; Gordon, 1995; Kohler \& Wiley, 1997). Riseng et al. (2004) found significant inter-annual differences in grazer and filter-feeder populations at our revisited sites (paired $t$-test, $p<0.05$ ) and that peak discharge and benthic chlorophyll levels were not correlated among sites between years.

Each assessment involved 8-9 visits to KY streams and $\leq 4$ visits to MI streams during a 2-month sampling period. A higher sampling frequency was used in KY versus MI because hydrologic variability was less and sites were much farther apart in MI than KY. During these weekly or biweekly visits, discharge was assessed with a Marsh-McBirney current meter; $\mathrm{pH}$ and conductivity were determined with a YSI meter (YSI Incorporated, Yellow Springs, Ohio, USA); water temperature was determined with a thermometer; 
and canopy cover was assessed with a spherical canopy densiometer. Samples for nutrient and chloride assessments were collected in $2125-\mathrm{ml}$ acid-rinsed polyethylene bottles. Water in one sample was filtered in the field through $0.45-\mu \mathrm{m}$ pore-size filters to measure dissolved nutrients. Nutrient samples were stored on ice until returning to the lab where they were frozen until analysis.

Rapid periphyton surveys were also conducted during the weekly or biweekly visits to a site. This protocol was used for assessing algal biomass visually at larger spatial scales than practical when scraping algae on rocks and for distinguishing biomass composed of major phyla and growth forms of algae. A viewing bucket was constructed with the bottom cut out of a plastic tub and replaced with a clear plastic circle with a watertight seal. Use of a viewing bucket reduced glare from sunlight on the water surface and improved visibility of the bottom in these streams with relatively high light levels. A 50-point grid was marked on the bottom plastic circle to facilitate characterizing the percent of stream bottom in different conditions. Visual assessments were taken at nine locations throughout the targeted riffle at each site. Each assessment involved submerging the bottom of the viewing bucket in the water and characterizing: (1) \% of the bottom covered by macroalgae (e.g., Cladophora); (2) the average cover of suitable substrata ( $>2 \mathrm{~cm}$ diameter); and (3) thickness of the each different type of microalgae (e.g., diatoms and blue-green algae). Thickness of microalgae was characterized with a ranking system in which: 0 indicated the rock felt rough and had very little or no periphyton; 0.5 indicated the rock felt slippery, but no periphyton could be seen; 1 indicated periphyton was visible in a very thin biofilm; 2 indicated periphyton with a thickness $>$ thin biofilm but $\leq 1 \mathrm{~mm} ; 3$ indicated periphyton with a thickness $>1 \mathrm{~mm}$ but $\leq 5 \mathrm{~mm} ; 4$ indicated periphyton with a thickness $>5 \mathrm{~mm}$ but $\leq 2 \mathrm{~cm}$; and 5 indicated periphyton $>2 \mathrm{~cm}$ thick. The average diatom thickness rank and chl $a$ (method described later) were determined separately on 50 rocks to assess the reliability of visual assessments of diatom biomass.

Algae on rocks were sampled during the last two weeks of the 2-month sampling period and more than 5 days after a moderate storm event. Benthic algae were sampled using a spoon and toothbrush from the tops of 15 rocks randomly selected in the riffle at each site. Subsamples for different assays were separated in the field and stored on ice for chl $a$ and mat chemistry analysis and preserved with M3 for AFDM assays. Estimates of rock surface areas from which algae were scraped were made in the field by measuring the upper surface of rocks.

Water samples were analyzed for $\mathrm{Cl}$, $\mathrm{NO}_{3}+\mathrm{NO}_{2}\left(\mathrm{NO}_{x}\right)$, and $\mathrm{NH}_{4}$ using a Skalar ${ }^{\circledR}$ auto-analyzer, for soluble reactive $\mathrm{P}$ (SRP) using a Hitachi ${ }^{\circledR}$ U-2001 spectrophotometer, and for alkalinity according to standard methods (APHA, 1998). To determine TP and TN concentrations, particulate matter in water samples was oxidized with persulfate and analyzed for SRP and $\mathrm{NO}_{x}$ (D'Elia et al., 1977; APHA, 1998). Mat chemistries were determined by subsampling portions of mats and analyzing the samples for TN and TP as described for water samples. Mat chemistries were calculated as the proportion of $\mathrm{N}$ and $\mathrm{P}$ in periphyton samples (including algae, meiofauna, bacteria, detritus, and silt) by dividing the mass of $\mathrm{N}$ and $\mathrm{P}$ in samples by the AFDM. AFDM was measured after drying samples in aluminum pans and ashing at $500{ }^{\circ} \mathrm{C}$ (APHA, 1998). Chlorophyll $a$ was extracted from algal samples with $90 \%$ buffered acetone and measured spectrophotometrically (APHA, 1998).

\section{Data analysis}

Simple correlation, linear and non-linear regression, and multivariate regression approaches were used to determine relationships between algal biomass and nutrient concentrations in streams of the two regions. All statistical analyses were calculated using SYSTAT ${ }^{\circledR}$ version 10 (Wilkinson, 1990). Variables with skewed distributions were natural-log transformed to produce more even and normal distributions. Descriptive statistics and $t$-tests were used to determine whether significant differences in environmental conditions occurred between regions. Covariance matrices for nutrient concentrations and algal biomass were calculated independently to evaluate differences among regions. Correlations between the three algal biomass attributes (benthic chl $a$, diatom rank, average Cladophora cover during the 
sampling period) and average nutrient concentrations at sites were calculated independently for each region and for both regions combined to determine the importance of region for explaining variation in algal biomass-nutrient relationships. A fourth algal biomass attribute, maximum Cladophora cover at a site during a sampling period, was included in assessment of the probability of different average and maximum Cladophora covers occurring in streams with different nutrient concentrations.

Linear and non-linear regression analyses were used to test the hypothesis that non-linear models explained significantly more variation in algal biomass-nutrient relationships than linear models. The Monod equation was modified for the nonlinear model,

$$
B=B_{\max } *\left(S /\left(S+K_{\mathrm{s}}\right)\right)
$$

where biomass $(B)$ are predicted as a function of the maximum biomass possible $\left(B_{\max }\right)$, nutrient concentrations $(S)$, and a nutrient concentration at which half of $B_{\max }$ would occur $\left(K_{\mathrm{s}}\right)$. The Monod model was selected a priori because we hypothesized that algal biomass would increase rapidly and then saturate with progressive increases in nutrient concentrations in the same way as growth rates. Stepwise multiple regression was used to determine whether TN and TP explained more variation in algal biomass than either nutrient alone or whether other environmental factors such as canopy cover accounted for unexplained variation in biomass-nutrient relationships. TN and TP were used in detailed analyses because these parameters are recommended for nutrient criteria development (USEPA, 1999) and they indicate nutrient availability as well or better than other parameters (Dodds, 2003) The Z-test (Zar, 1974) was used to compare the correlations among analyses and to determine whether differences in the amount of variance explained were statistically significant. Difference in algal responses to nutrients between regions was determined by direct comparison of regression coefficients with standard errors of coefficients and $t$-statistics (Zar, 1974). Analysis of covariance was not used to compare relationships between regions because error variances could theoretically be very different in the two regions.
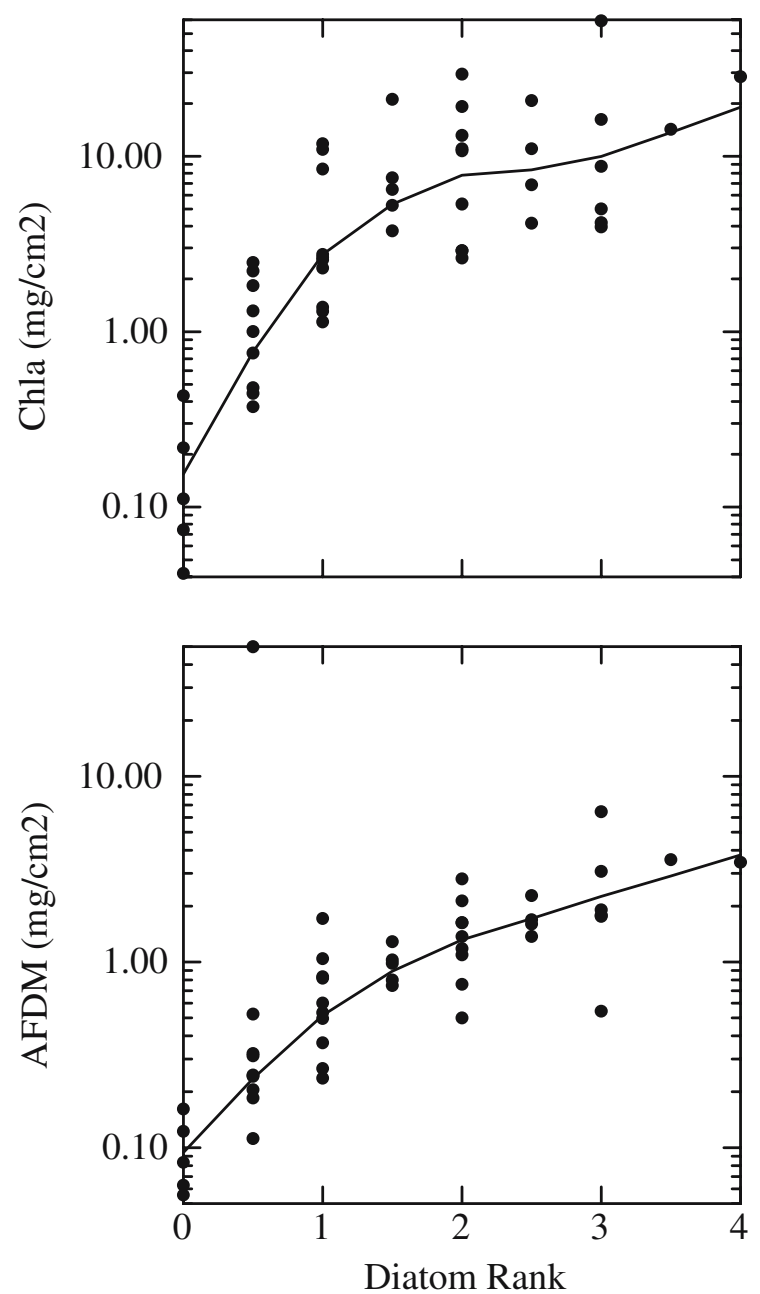

Figure 2. Relationships between chl $a$ and AFDM and diatom rank determined by assessment of individual rocks to assess the precision of visual assessments. Lines on figures produced by lowess smoothing (Wilkinson, 1990).

\section{Results}

\section{Accuracy of rapid periphyton survey}

Estimates of diatom biomass using thickness rank explained over 58 and $46 \%$ of the variation in diatom biomass estimated, respectively, with ln-transformed chl $a$ and ln-transformed AFDM of periphyton on rocks (Fig. 2). The non-linear pattern in log-transformed chl $a$ with increasing diatom rank increased variance explained to $71 \%$ by using polynomial regression. The non-linear pattern in AFDM with increasing diatom rank 

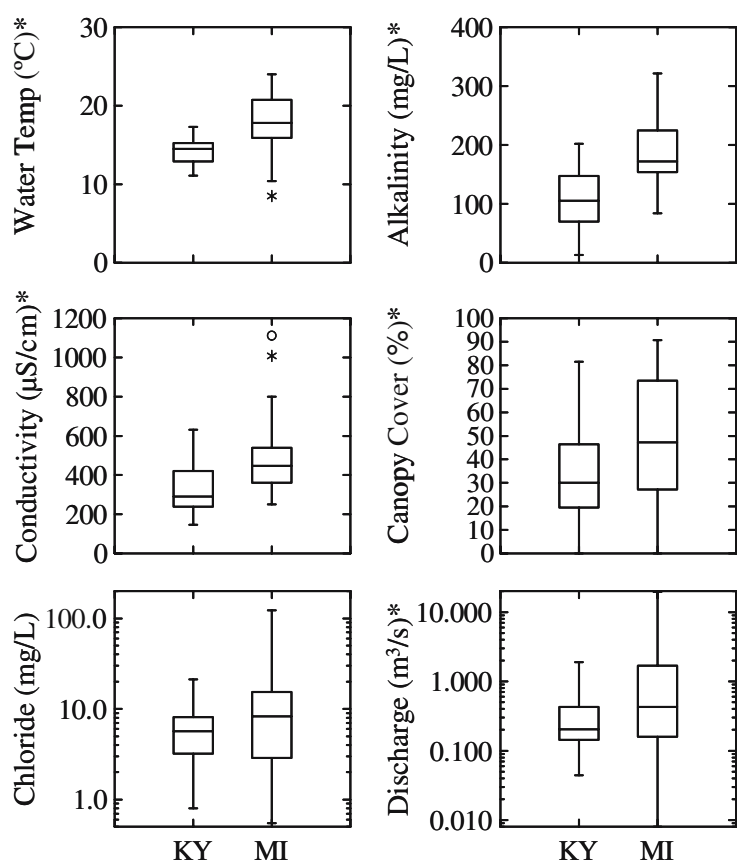

\section{Region}

Figure 3. Comparison of non-nutrient abiotic factors between $\mathrm{KY}$ and MI. Asterisks indicate mean values were different among ecoregions $(t$-test, $p<0.005)$.

was not statistically significant and explained little additional variation compared to the linear model.

\section{Comparison of stream conditions between $K Y$ and $M I$}

Averages of almost all non-nutrient parameters, except $\mathrm{Cl}$, were significantly different between regions ( $t$-tests, $p<0.05$ ), but ranges of parameters overlapped greatly (Fig. 3). Results indicated that our study streams were moderately buffered with alkalinity averaging 109 and $187 \mathrm{mg}^{-1}$ and $\mathrm{pH}$ 8.04 and 7.94 in the KY and MI, respectively. Conductivity was lower in KY than MI. Average water temperatures during the sampling periods were lower in $\mathrm{KY}$ than $\mathrm{MI}\left(14.2\right.$ and $18.0^{\circ} \mathrm{C}$, respectively), streams were smaller in $\mathrm{KY}$ than MI (discharge was 0.32 and $1.52 \mathrm{~m}^{3} \mathrm{~s}^{-1}$, respectively), but ranges in both temperature and discharge overlapped in the two regions. Ranges in canopy cover $(0->80 \%$ cover $)$ and chloride concentrations $\left(0.5-123.5 \mathrm{mg} \mathrm{l}^{-1}\right)$ also overlapped greatly between the two regions.
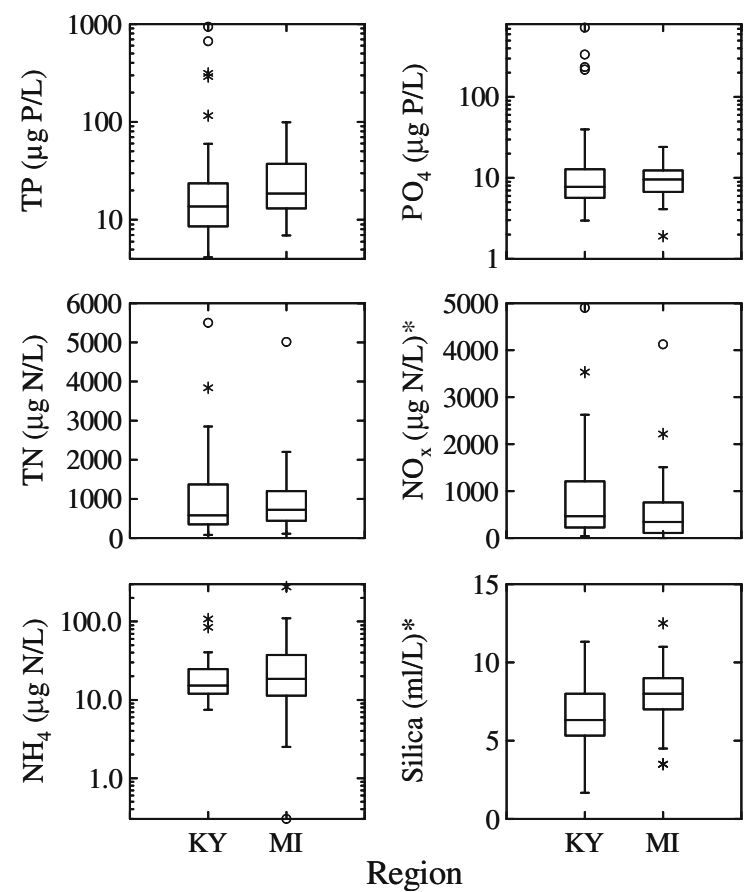

Figure 4. Comparison of nutrient concentrations between KY and MI. Asterisks indicate mean values were different among ecoregions ( $t$-test, $p<0.005)$.

Average concentrations of TP, SRP, TN and $\mathrm{NH}_{4}$ and ratios of $\mathrm{N}: \mathrm{P}$ in water and P:AFDM did not differ between regions and wide ranges in nutrient conditions were observed (Fig. 4). However, $\mathrm{NO}_{x}, \mathrm{Si}$, mat $\mathrm{N}: \mathrm{P}$ ratios, and mat $\mathrm{N}$ :AFDM ratios differed between regions, even though their ranges overlapped greatly. Many observations of SRP and TP concentrations were less than $10 \mu \mathrm{g}$ $\mathrm{P}^{-1}$ and some were greater than $100 \mu \mathrm{g} \mathrm{1^{-1 }}$. SRP averaged $62 \%$ of TP in KY and only $36 \%$ of TP of MI. All but four TP concentrations in KY were less than $100 \mu \mathrm{g}^{-1}$. Figures illustrating algal response to TP were limited to less than 100 to optimize use of space and more clearly illustrate changes in algal biomass with TP. Silica concentrations ranged from 1.7 to $12.5 \mathrm{mg}^{-1}$ with averages of 6.5 and 8.0 in the two regions. Molar N:P ratios averaged 103 and 84 in the water and 11.3 and 9.2 in periphyton in $\mathrm{KY}$ and $\mathrm{MI}$, respectively. $\mathrm{NO}_{x}$ and $\mathrm{TN}$ concentrations were often less than 50 and $100 \mu \mathrm{g} \mathrm{N} 1^{-1}$ respectively, and as high as $5497 \mu \mathrm{g} \mathrm{TN}{ }^{-1}$. $\mathrm{NO}_{x}$ was 60 and $83 \%$ of TN in the KY and MI, respectively. $\mathrm{NH}_{4}$, ranging from less than $5-277 \mu \mathrm{g} \mathrm{N} \mathrm{1}^{-1}$, was less than $5 \%$ of $\mathrm{TN}$ in both regions. 


\section{Relations between nutrients and environmental factors}

Nutrient concentrations were highly correlated with each other, but were not highly correlated with alkalinity, canopy cover, and discharge. Pearson correlations among nutrient concentrations were higher among KY than MI streams, with all $r$ being greater than 0.6 in $\mathrm{KY}$ and less than $50 \%$ of $r$ being greater than 0.6 in MI (Table 1). Conductivity and $\mathrm{Cl}$ were correlated to nutrients in the MI and $\mathrm{KY}$, but $\mathrm{pH}$ was correlated significantly with nutrient concentrations only in KY streams.

Even though $\ln (\mathrm{TP})$ and $\ln (\mathrm{TN})$ in streams were correlated with each other in $\mathrm{KY}$ and MI $(r=0.69$ and $r=0.62$, respectively), many high $\mathrm{N}$ sites had low P concentrations. However, low N sites with high $\mathrm{P}$ were absent from the possible combinations of nutrient conditions in both regions. SRP and TP were more highly correlated in $\mathrm{KY}$ than $\mathrm{MI}(Z$-test, $p<0.05)$. $\mathrm{NO}_{x}$ was highly correlated with $\mathrm{TN}$ in both regions and more highly correlated with $\mathrm{TN}$ than $\mathrm{NH}_{4}$.

\section{Determining algal biomass relations with nutrients}

Variability in most measures of algal biomass was great in both regions (Fig. 5). Benthic chl $a$ varied from $<0.1 \mu \mathrm{g} \mathrm{cm}^{-2}$ to $>40 \mu \mathrm{g} \mathrm{cm}^{-2}$. Average diatom rank at a site varied from less than 0.5 to about 2.0. Average and maximum Cladophora cover at a site varied from 0 to $80 \%$. Benthic chl $a$ and diatom rank were significantly greater in $\mathrm{KY}$ (averaging $13.0 \mu \mathrm{g} \mathrm{chl} a \mathrm{~cm}^{-2}$ and thickness rank $=0.92$ ) than MI (averaging $4.1 \mu \mathrm{g} \mathrm{chl} a \mathrm{~cm}^{-2}$ and rank $=0.55$ ).

Correlations between all measures of $\mathrm{N}$ or $\mathrm{P}$ concentrations and measures of algal biomass were positive (Table 2) and more than half were statistically significant $(p<0.05$, without Bonferroni correction). Diatom rank was not significantly correlated to nutrient concentration in either region, except for $\mathrm{NH}_{4}$. Diatom abundances ranged widely from low to high ranks at all nutrient concentrations in $\mathrm{KY}$, but ranged little in MI streams unless nutrient concentrations were really high (Fig. 4).

Correlations between nutrients and algal attributes were higher for specific regions than when
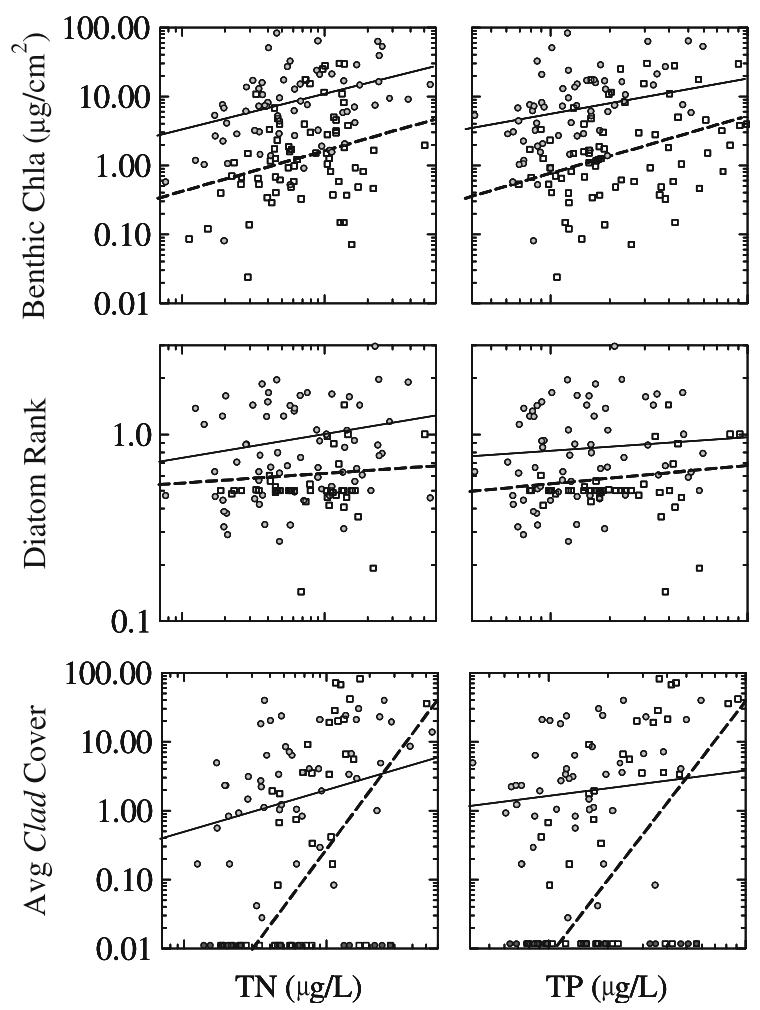

Figure 5. Individual relationships between benthic chl $a$, diatom thickness rank, and average Cladophora cover and average total nitrogen (TN) and total phosphorus (TP) concentrations in streams in two regions, the Knobs (shaded circles) and the glaciated region (squares circles). The lines indicate the best fit of linear regression for streams in the Knobs (solid line) and in the glaciated region (dashed line). Statistical significance of the relationships can be found in Table 4 .

data from both regions were combined (Table 2), especially for the most highly correlated algal attributes. For example, correlations between Cladophora cover and total nutrients averaged 0.354 when data for both regions were combined; they were significantly less $(Z$-test, $p<0.05)$ than the average $r=0.608$ in MI where Cladophora cover was most highly correlated with TP and TN. Benthic chl $a$ was better correlated to all nutrients in $\mathrm{KY}$ streams than when streams from MI were included in calculations.

$\mathrm{NO}_{3}$, SRP, TN, and TP were similarly correlated with measures of algal biomass, except for low correlations between SRP and Cladophora cover in MI. Correlations tended to be higher between measures of algal biomass and $\mathrm{NH}_{4}$ than other nutrient concentrations. Algal biomass 
Table 1. Correlations among water chemistry parameters in streams of the Knobs and glaciated region

\begin{tabular}{|c|c|c|c|c|c|c|c|c|c|c|}
\hline & $\mathrm{pH}$ & Alk & CanCov & Cond & $\mathrm{Cl}$ & $\mathrm{NO}_{x}$ & $\mathrm{NH}_{4}^{+}$ & $\mathrm{TN}$ & SRP & Region \\
\hline Alkalinity & 0.568 & & & & & & & & & Knobs \\
\hline Canopy cover & 0.368 & 0.12 & & & & & & & & Knobs \\
\hline Conductivity & 0.515 & 0.87 & -0.007 & & & & & & & Knobs \\
\hline Chloride & 0.278 & 0.279 & 0.120 & 0.456 & & & & & & Knobs \\
\hline $\mathrm{NO}_{3}$ & 0.235 & 0.150 & 0.203 & 0.299 & 0.758 & & & & & Knobs \\
\hline $\mathrm{NH}_{4}$ & 0.353 & 0.185 & 0.336 & 0.339 & 0.675 & 0.602 & & & & Knobs \\
\hline $\mathrm{TN}$ & 0.272 & 0.205 & 0.218 & 0.346 & 0.786 & 0.984 & 0.663 & & & Knobs \\
\hline SRP & 0.407 & 0.158 & 0.308 & 0.348 & 0.582 & 0.600 & 0.733 & 0.639 & & Knobs \\
\hline TP & 0.418 & 0.248 & 0.255 & 0.421 & 0.649 & 0.645 & 0.749 & 0.694 & 0.960 & Knobs \\
\hline Alkalinity & -0.039 & & & & & & & & & Glaciated \\
\hline Canopy cover & 0.081 & 0.054 & & & & & & & & Glaciated \\
\hline Conductivity & 0.269 & 0.331 & 0.111 & & & & & & & Glaciated \\
\hline Chloride & 0.243 & 0.082 & 0.099 & 0.814 & & & & & & Glaciated \\
\hline $\mathrm{NO}_{3}$ & 0.093 & 0.087 & 0.013 & 0.528 & 0.460 & & & & & Glaciated \\
\hline $\mathrm{NH}_{4}$ & 0.168 & 0.088 & 0.083 & 0.649 & 0.662 & 0.281 & & & & Glaciated \\
\hline $\mathrm{TN}$ & 0.204 & 0.014 & -0.081 & 0.601 & 0.554 & 0.852 & 0.435 & & & Glaciated \\
\hline SRP & -0.029 & 0.383 & 0.029 & 0.514 & 0.455 & 0.284 & 0.616 & 0.333 & & Glaciated \\
\hline TP & 0.308 & 0.010 & 0.107 & 0.644 & 0.588 & 0.465 & 0.659 & 0.616 & 0.482 & Glaciated \\
\hline
\end{tabular}

correlations with total nutrients were about the same as with dissolved nutrients. Silica concentrations were negatively correlated with benthic chl $a$ and Cladophora cover in KY and when data for both regions were combined.

Multivariate and non-linear models did not explain significantly more variation in algal biomass than univariate linear models using $\mathrm{TN}$ and TP. If $r^{2}$ of multivariate and non-linear models were greater than for univariate linear models, then they were not more than $20 \%$ greater.
Only 4 of 36 correlations were statistically significant $(p<0.05)$ between algal biomass measures and either water column N:P ratios or periphyton $\mathrm{P} / \mathrm{AFDM}, \mathrm{N} / \mathrm{AFDM}$, or N:P ratios (Table 3). Significantly positive correlations were observed between chl $a$ and N/AFDM in MI and both regions together, between diatom rank and $\mathrm{N} / \mathrm{AFDM}$ in both regions together, and between chl $a$ and mat N:P ratio in MI streams. Water column N:P ratios were not related to algal biomass in either region.

Table 2. Correlations between measures of benthic algal biomass and nutrient indicators independently in streams of the Knobs and glaciated region and jointly with data from both regions

\begin{tabular}{|c|c|c|c|c|c|c|c|}
\hline Region & Biomass variable & $\ln (\mathrm{TN})$ & $\ln (\mathrm{TP})$ & $\ln \left(\mathrm{NO}_{x}\right)$ & $\ln \left(\mathrm{NH}_{4}\right)$ & $\ln (\mathrm{SRP})$ & $\ln (\mathrm{Si})$ \\
\hline Knobs & $\ln ($ ben chl $a)$ & 0.433 & 0.416 & 0.399 & 0.521 & 0.369 & -0.348 \\
\hline Knobs & $\ln ($ dia rank) & 0.177 & 0.124 & 0.141 & 0.336 & 0.136 & 0.116 \\
\hline Knobs & $\ln ($ Clad cov $)$ & 0.289 & 0.224 & 0.267 & 0.200 & 0.176 & -0.379 \\
\hline Glaciated & $\ln ($ ben chl $a$ ) & 0.298 & 0.320 & 0.164 & 0.528 & 0.436 & 0.176 \\
\hline Glaciated & $\ln ($ dia rank) & 0.223 & 0.298 & 0.167 & 0.471 & 0.142 & -0.059 \\
\hline Glaciated & $\ln ($ Clad cov $)$ & 0.548 & 0.668 & 0.469 & 0.523 & 0.129 & 0.048 \\
\hline Both & $\ln ($ ben chl $a$ ) & 0.269 & 0.229 & 0.313 & 0.393 & 0.318 & -0.263 \\
\hline Both & $\ln ($ dia rank) & 0.126 & 0.104 & 0.181 & 0.280 & 0.139 & -0.065 \\
\hline Both & $\ln ($ Clad cov $)$ & 0.368 & 0.340 & 0.355 & 0.361 & 0.145 & -0.217 \\
\hline
\end{tabular}

Correlation coefficients $(r)$ in bold indicate statistical significance with $p<0.05$. 
Table 3. Correlations between measures benthic algal biomass, nutrient ratios in the water, mat nutrient concentrations and ratios, and other stream chemistry and habitat parameters (CanCov, canopy cover; $\mathrm{Cl}$, chloride; and cond, conductivity)

\begin{tabular}{|c|c|c|c|c|c|c|c|c|}
\hline \multirow[t]{2}{*}{ Region } & \multirow[t]{2}{*}{ Biomass variable } & \multirow[t]{2}{*}{ Water N:P } & \multicolumn{3}{|l|}{ Mat } & \multirow[t]{2}{*}{ CanCov } & \multirow[t]{2}{*}{$\ln (\mathrm{Cl})$} & \multirow[t]{2}{*}{$\ln ($ cond $)$} \\
\hline & & & $\mathrm{P} / \mathrm{AFDM}$ & N/AFDM & $\mathrm{N}: \mathrm{P}$ & & & \\
\hline Knobs & ln (ben chl $a$ ) & -0.045 & -0.184 & -0.156 & 0.100 & 0.374 & 0.540 & 0.419 \\
\hline Knobs & $\ln$ (dia rank) & 0.039 & -0.036 & -0.091 & -0.097 & 0.351 & 0.057 & 0.090 \\
\hline Knobs & $\ln ($ Clad cov $)$ & 0.049 & -0.047 & -0.118 & -0.127 & 0.196 & 0.422 & 0.538 \\
\hline Glaciated & $\ln ($ ben chl $a)$ & -0.058 & 0.246 & 0.412 & 0.111 & -0.23 & 0.314 & 0.386 \\
\hline Glaciated & $\ln$ (dia rank) & -0.08 & -0.070 & -0.254 & -0.193 & -0.228 & 0.327 & 0.421 \\
\hline Glaciated & $\ln (\mathrm{Clad}$ cov $)$ & -0.141 & -0.115 & 0.163 & 0.244 & -0.072 & 0.583 & 0.589 \\
\hline Both & $\ln ($ ben chl $a)$ & 0.028 & 0.185 & 0.463 & 0.273 & -0.129 & 0.260 & 0.091 \\
\hline Both & $\ln$ (dia rank) & 0.041 & 0.180 & 0.322 & 0.211 & 0.114 & 0.100 & -0.036 \\
\hline Both & $\ln ($ Clad cov $)$ & -0.020 & 0.008 & 0.123 & 0.154 & 0.073 & 0.501 & 0.493 \\
\hline
\end{tabular}

Correlation coefficients $(r)$ in bold indicate statistical significance with $p<0.05$.

Canopy cover was positively correlated $(p<0.05)$ to chl $a$ and diatom rank in KY, but was not related to algal biomass in other cases (Table 3). Even Cladophora cover was not related significantly to canopy cover. Correlations between chl a/AFDM ratios and canopy cover were $r=0.444$ in $\mathrm{KY}$ and $r=-0.014$ in MI.

Chloride concentration and conductivity were positively correlated $(p<0.05)$ with measures of algal biomass in both KY and MI. Correlations between these indicators of human disturbance and algal biomass were usually higher than correlations between nutrient concentrations and algal biomass (Table 3).

\section{Comparison of biomass-nutrient models between regions}

Algal biomass was usually lower in MI than KY, as indicated by the significantly lower constants in MI than KY in TP models (Fig. 5, Table 4). However, responses of benthic algal biomass to nutrients seemed to be due to changes in Cladophora versus epilithic diatom biomass, and these were higher in MI than KY. Chl $a$ increased with nutrients in both regions at approximately the same rate, approximately $0.6 \mu \mathrm{g} \mathrm{chl} a \mathrm{~cm}^{-2}$ per $\mathrm{ln}$ $\left(\mu \mathrm{g} 1^{-1}\right)$ of both TP and TN. Diatom thickness rank did not increase significantly with nutrients in either region, however Cladophora cover did. TN and TP models indicated that Cladophora cover was lower in low nutrient conditions in the MI than KY, but increased faster with nutri- ent enrichment in MI. The constants for models relating TN and TP with Cladophora cover were significantly lower in the MI than KY for both TN and TP models, but slopes for these models were higher in the MI than KY. The slope for the Cladophora/TP model was not significantly different than 0.0 in $\mathrm{KY}(p=0.058)$.

\section{Cladophora cover}

Due to differences in Cladophora/nutrient models between regions, differences in percent cover in different nutrient regimes were examined more closely (Figs. 6 and 7). The probability of observing average Cladophora cover $<1 \%$ in a stream was negatively related (Spearman rank correlations, $p>0.05$ ) to nutrient concentrations in MI, but not in KY. However, Cladophora accrual was severely constrained in low nutrient streams in both regions. Average Cladophora cover was less than $1 \%$ in all streams of MI having less than $300 \mu \mathrm{g} \mathrm{TN} 1^{-1}$ and $10 \mu \mathrm{g} \mathrm{TP} 1^{-1}$. Thirty and fifty percent of KY streams in that low nutrient category $\left(300 \mu \mathrm{g} \mathrm{TN} ~^{-1}\right.$ and $\left.10 \mu \mathrm{g} \mathrm{TP} 1^{-1}\right)$ had, respectively, average and maximum Cladophora cover $<1 \%$. In addition, only 1 of 25 of these low nutrient KY streams had average Cladophora cover $>10 \%$ and only 3 of 25 had maximum cover $>10 \%$.

The probability of maximum Cladophora being $>40 \%$ increased significantly (Spearman rank correlations, $p>0.05$ ) with both $\mathrm{TN}$ and $\mathrm{TP}$ conditions in both regions. The probability of average Cladophora cover being greater than $10 \%$ 
Table 4. Linear regression statistics for relationships between six measures of algal biomass and nutrient conditions in streams of $\mathrm{KY}$ and $\mathrm{MI}$

\begin{tabular}{|c|c|c|c|c|c|c|c|}
\hline Dependent variable & Independent variable & Region & Constant & Constant (SE) & Slope & Slope (SE) & Model $p$ \\
\hline $\ln (\operatorname{chl} a)$ & $\ln (\mathrm{TN})$ & KY & -2.098 & 1.035 & 0.62 & 0.16 & $<0.001$ \\
\hline $\ln (\operatorname{chl} a)$ & $\ln (\mathrm{TN})$ & MI & -3.859 & 1.625 & 0.639 & 0.247 & 0.012 \\
\hline $\ln (\operatorname{chl} a)$ & $\ln (\mathrm{TN})$ & both & -2.389 & 1.07 & 0.535 & 0.164 & 0.001 \\
\hline $\ln (\operatorname{chl} a)$ & $\ln (\mathrm{TP})$ & KY & 0.408 & 0.422 & 0.521 & 0.239 & $<0.001$ \\
\hline $\ln (\operatorname{chl} a)$ & $\ln (\mathrm{TP})$ & MI & -1.908 & 0.813 & 0.72 & 0.256 & 0.006 \\
\hline $\ln (\operatorname{chl} a)$ & $\ln (\mathrm{TP})$ & both & -0.167 & 0.471 & 0.42 & 0.153 & 0.007 \\
\hline ln (diatom rnk) & $\ln (\mathrm{TN})$ & KY & 0.298 & 0.214 & 0.049 & 0.033 & 0.137 \\
\hline ln (diatom rnk) & $\ln (\mathrm{TN})$ & MI & 0.155 & 0.188 & 0.041 & 0.028 & 0.15 \\
\hline ln (diatom rnk) & $\ln (\mathrm{TN})$ & both & 0.317 & 0.172 & 0.035 & 0.026 & 0.18 \\
\hline ln (diatom rnk) & $\ln (\mathrm{TP})$ & KY & 0.529 & 0.089 & 0.03 & 0.029 & 0.299 \\
\hline ln (diatom rnk) & $\ln (\mathrm{TP})$ & MI & 0.245 & 0.093 & 0.06 & 0.03 & 0.053 \\
\hline ln (diatom rnk) & $\ln (\mathrm{TP})$ & both & 0.467 & 0.074 & 0.027 & 0.024 & 0.269 \\
\hline $\ln ($ avg Clad cov) & $\ln (\mathrm{TN})$ & KY & -1.287 & 0.953 & 0.369 & 0.146 & 0.014 \\
\hline ln (avg Clad cov) & $\ln (\mathrm{TN})$ & MI & -6.717 & 1.875 & 1.179 & 0.611 & $<0.001$ \\
\hline $\ln ($ avg Clad cov) & $\ln (\mathrm{TN})$ & Both & -2.583 & 0.881 & 0.564 & 0.136 & $<0.001$ \\
\hline $\ln ($ avg Clad cov) & $\ln (\mathrm{TP})$ & KY & 0.367 & 0.4 & 0.251 & 0.13 & 0.058 \\
\hline $\ln ($ avg Clad cov) & $\ln (\mathrm{TP})$ & MI & -3.667 & 0.848 & 1.567 & 0.273 & $<0.001$ \\
\hline $\ln ($ avg Clad cov) & $\ln (\mathrm{TP})$ & Both & -0.317 & 0.385 & 0.48 & 0.125 & $<0.001$ \\
\hline
\end{tabular}

The relations between biomass and TP differ from those illustrated in Figure 4 due to limiting the TP range to $<100 \mu \mathrm{g} 1^{-1}$. SE, standard error. Bold statistics indicate a statistically significant difference $(p<0.05)$ between KY and MI using either pooled estimates of variance or individual estimates of variance. Bold statistics in italics indicate a statistically significant relationship between KY and MI using pooled estimates of variance only.

increased with TN and TP conditions in MI, but not KY. Between 20 and $50 \%$ increases in the likelihood of high Cladophora cover $(>20 \%$ average and $>40 \%$ maximum cover) were observed in MI when TP exceeded $30 \mu \mathrm{g}$ TP $1^{-1}$ and $1000 \mu \mathrm{g}$ $\mathrm{TN} 1^{-1}$. Similarly great increases were not observed in $\mathrm{KY}$, but clear evidence of positive relationships between likelihood of high Cladophora cover and $\mathrm{TP}$ and TN concentrations during peak accrual periods were observed there (Figs. 6 and 7).

\section{Discussion}

\section{Algal-nutrient relations}

Variation in benthic algal biomass among streams was related to nutrient concentrations, but some relationships changed with region and between diatoms and the macroalga Cladophora. Total benthic algal biomass increased in both MI and $\mathrm{KY}$ with increasing concentrations of both soluble and total nutrient concentrations. However, most of the predictable increase in biomass was probably due to an increase in Cladophora cover. Epilithic diatom biomass did not increase significantly with increasing nutrient concentrations in either region.

Algal biomass was similarly related to TN, TP, and soluble nutrients (except $\mathrm{NH}_{4}^{+}$concentration). Dodds (2003) recently reviewed the rationale for total nutrients being better indicators of nutrient supply than soluble nutrients and clearly relates nutrient demand, uptake, and empirical evidence to this issue. However, Biggs (2000) was able to relate benthic algal biomass to soluble nutrients by using annual means of dissolved nutrient concentrations as an indicator of nutrient supply and accounting for time of accrual after disturbance. Our two-month averages in nutrient concentrations in KY streams may also have provided an indicator of nutrient supply. However, the lower variability in algal-nutrient relations in our study than in other large-scale regional studies (Bourassa \& Cattaneo, 1998; Dodds et al., 1998, 2002; Biggs, 


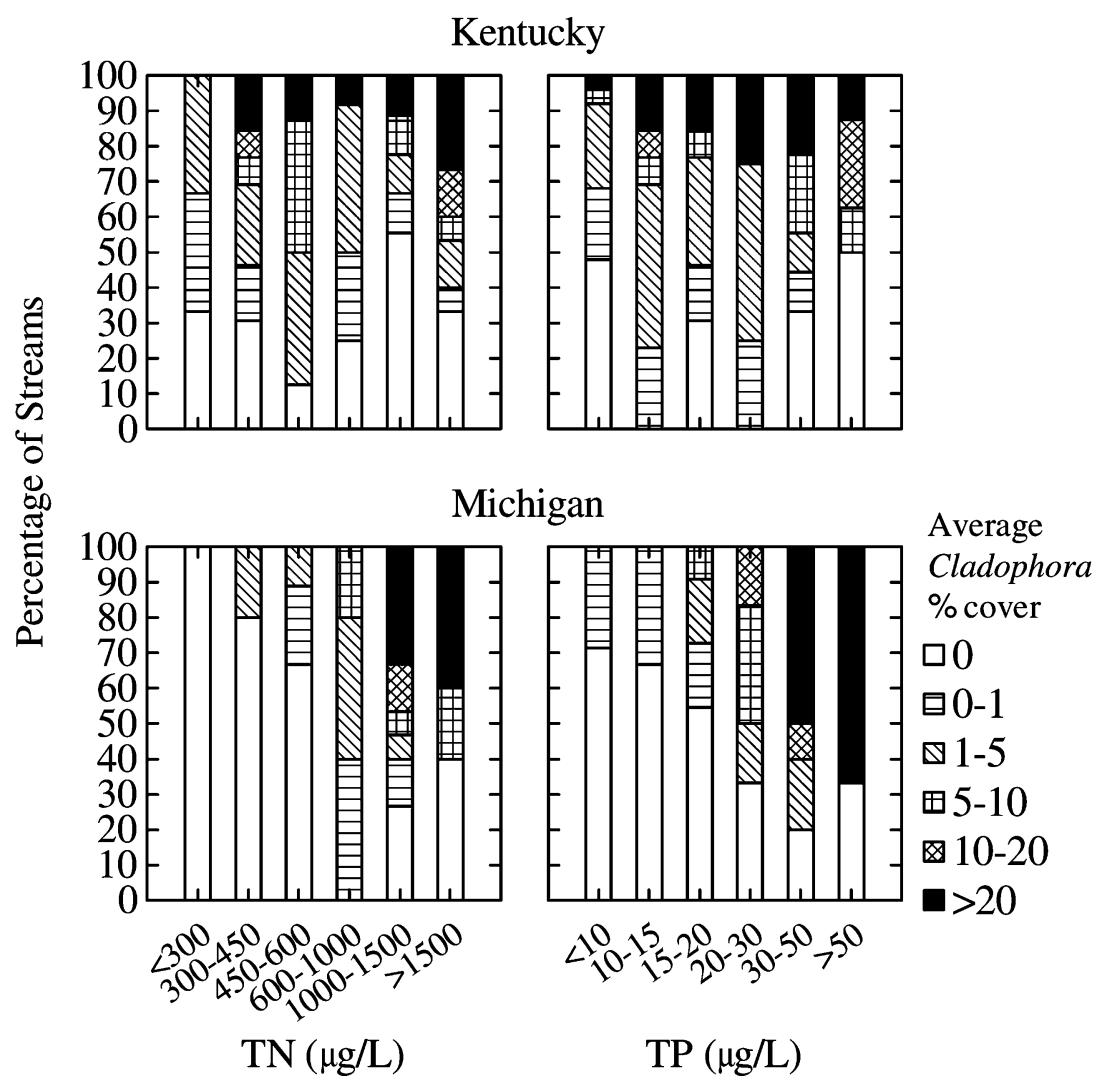

Figure 6. Histograms representing the percentage of streams in different nutrient categories and in different regions with increasing cover of Cladophora. Width of the bands in each bar represents the percentage of streams in a nutrient category with specific ranges of average Cladophora cover. Codes for those ranges are in the legend.

2000) is probably due to other factors as well, such as distinguishing responses of diatoms and Cladophora and controlling for effects of in-stream spatial variation and regions.

Differing responses of diatoms and Cladophora may be due to differences in physiological requirements for nutrients or to differences in density-related constraints of nutrient supply through thick diatom and Cladophora accumulations. Accrual of even thick growths of diatoms is saturated in experiments around $30 \mu \mathrm{g} \mathrm{P} \mathrm{1^{-1 }}$ (Bothwell, 1989; Rier \& Stevenson, accepted), and the negative effects of mat density on solute mixing, nutrient supply rate, and benthic algal growth rates are great (Stevenson et al., 1991; Stevenson \& Glover, 1993). Little is known about effects of specific nutrient concentrations on Cladophora growth rates in streams (Dodds \& Gudder, 1992). The ability of Cladophora to develop thick, deep growths in streams (Dodds, 1991) and thick epiphyte covers may increase the demand of Cladophora for nutrients more than diatom-dominated periphyton.

The lack of response of diatoms to nutrients in either region was unexpected, especially in $\mathrm{KY}$ where diatom accrual was sometimes great. Greater variability in diatom biomasses in $\mathrm{KY}$ than MI were observed. Many KY streams had less than $30 \mu \mathrm{g} \mathrm{P}^{-1}$ and $300 \mu \mathrm{g} \mathrm{N} 1^{-1}$, which have been shown to limit accrual of peak biomasses of diatoms in experimental settings (Bothwell, 1989; Rier \& Stevenson, accepted). Even though error in nutrient assessments of streams was not sufficient to mask other algal-nutrient relationships, it may have masked diatom-nutrient relationships. Alternatively, high biomasses of algae can accumulate in low nutrient conditions if loss rates are low (e.g., Stevenson et al., 2002).

Differences in benthic diatoms between regions in our study were probably due to grazing by 


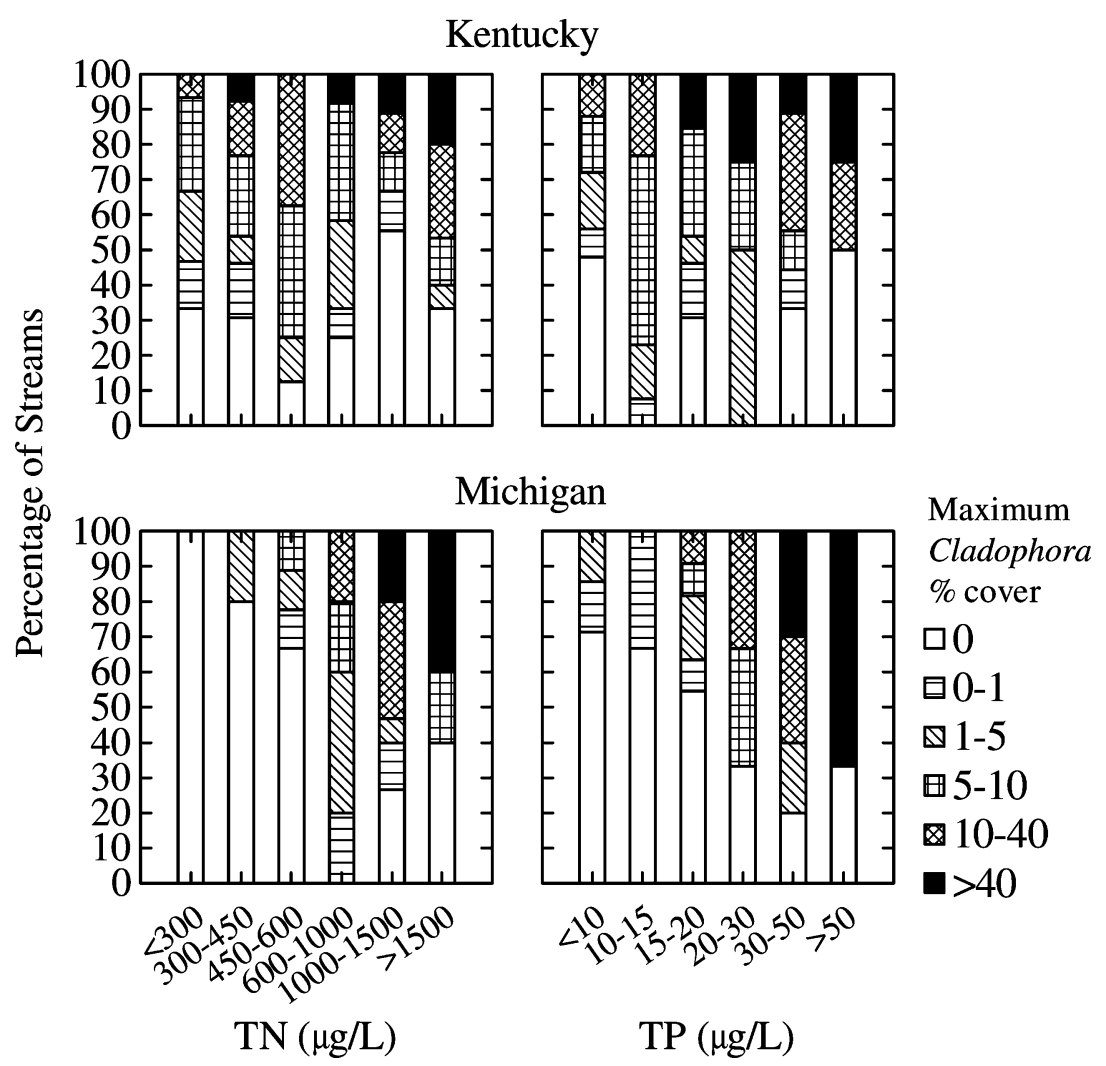

Figure 7. Histograms representing the cumulative frequency of streams in different nutrient categories and in different regions with increasing cover of Cladophora. Width of the bands in each bar represents the percentage of streams in a nutrient category with specific ranges of maximum Cladophora cover. Codes for those ranges are in the legend.

invertebrates. Benthic invertebrate biomass was much lower in streams of KY than MI. Low invertebrate biomass in the KY has been related to the more intense natural disturbance regime due to flooding and summer drought (Riseng et al., 2004). Invertebrate grazers are commonly associated with regulation of diatom-dominated periphyton (Lamberti \& Resh, 1983; Feminella \& Hawkins, 1995) and it is well documented in MI streams (Kohler \& Wiley, 1997). Although averages of many environmental conditions were statistically different between regions, their ranges overlapped greatly. It's unlikely that the statistically significant differences in water temperature, $\mathrm{pH}$, alkalinity, conductivity, and canopy cover were sufficient to be biologically significant and affect diatom or Cladophora biomass. Ranges in nutrient concentrations were very similar in the two regions.

Relationships between algae and nutrient concentrations varied greatly between regions and were probably related to inaccuracies in measuring nutrient availability, herbivory, and scouring by floods. Correlations between measures of algal biomass and nutrients were higher when observations were constrained to one region or another versus when data for both regions were combined. Although diatom biomass did not increase with nutrients in either region, Cladophora cover did increase with nutrients and more rapidly in MI than KY. The soluble fraction of TP was greater in KY than MI, so the greater responses of Cladophora to low nutrients in $\mathrm{KY}$ than MI may be due to a higher fraction of bioavailable P. Grazers can consume Cladophora (Dudley \& D'Antonio, 1991), thus lower \% cover of Cladophora in low nutrient streams of MI than KY (Figs. 5 and 6) may have been due to higher grazing pressure. Higher likelihood of extensive growths in high nutrient streams of the MI than KY may be due to less frequent flood disturbances in MI. 
Disturbance regime has been related to algal biomass in streams by Biggs (1995), who suggested that high disturbance regimes constrain algal biomass. This prediction seems to conflict with observations of lowest algal biomass in the low disturbance regimes of our glaciated region and below dams in other studies (Wootton et al., 1996). However, the mechanisms regulating the algal-nutrient relationships in different disturbance regimes and the range of disturbance regime probably account for differences in predictions. The Biggs model was developed in very high disturbance rivers draining high gradient mountain streams, which probably have more frequent and intense disturbances than the Knobs region of KY. Frequent, intense disturbances probably reduce the ability of periphyton to recolonize between storm events by scouring algae off substrata and preventing substantial recolonization. In the very low disturbance regimes of groundwater-fed, hydrologically stable streams in glaciated regions, we find high densities of grazers constraining diatom accrual. Thus, the greatest response of benthic algal biomass to nutrients is most likely at intermediate levels of disturbance, where sufficient time occurs between storm events for algal recolonization but not enough time for regrowth of sufficient invertebrate densities to constrain algal accrual. (Fig. 8)

\section{Nutrient criteria}

The primary purpose of establishing nutrient criteria is to prevent nuisance growths of algae. Nuisance growths may be related to benthic diatoms as well as proliferation of filamentous green algae in streams (Biggs, 2000). Response of Cladophora to nutrients should be given special consideration when establishing nutrient criteria to prevent in-stream nuisance algal growths. Filamentous green algae are prevalent in high biomass conditions (Chetelat et al., 1999), affect aesthetics, may cause local DO-depletion, and alter habitats in ways that affect invertebrates and fish (Dudley et al., 1986).

Two important issues for establishment of nutrient criteria are identifying which nutrient limits algal growth and determining the concentration of that nutrient enabling nuisance growths. Phosphorus is usually identified as the nutrient limiting algal growth in streams, however experiments show that $\mathrm{N}$ may also be a factor (Francoeur, 2001). Strength of correlations between biomass and nutrients and nutrient ratios has been used as evidence for likely $\mathrm{N}$ or $\mathrm{P}$ limitation. Using strength of correlations to indicate limiting nutrients in streams is problematic in streams because high benthic biomass may result in depletion of the most limiting nutrient in the water column. The negative relationship between $\mathrm{Si}$ and algal biomass in KY where high diatom biomasses develop demonstrates that nutrient demand is sufficient to deplete water column resources. The high correlation between $\mathrm{NH}_{4}^{+}$ concentration and algal biomass could indicate $\mathrm{N}$ limitation; $\mathrm{NH}_{4}^{+}$concentrations were very low, relative to $\mathrm{NO}_{x}$ and $\mathrm{TN}$ and $\mathrm{NH}_{4}^{+}$is assumed to be the preferred form of dissolved N. More likely, $\mathrm{NH}_{4}^{+}$is a good indicator of nutrient loading and supply by human activities, like $\mathrm{Cl}$ and conductivity.

Water and mat $\mathrm{N}: \mathrm{P}$ ratios, $\mathrm{P} / \mathrm{AFDM}$, and $\mathrm{N} /$ AFDM were poorly related to algal biomass in our study. The positive correlation between N/AFDM and diatom biomass was probably due to correspondence in regional differences in both $\mathrm{N} /$ AFDM and algal biomass rather than an indicator of $\mathrm{N}$ regulation of algal biomass. Both N/AFDM and diatom biomass were lower in MI than KY, but the low biomass in MI was most likely due to herbivory. Low N:P ratios in stream water were not related to algal biomass, which was probably again caused by the complexity in relationships between nutrient ratios, loading rates, absolute water column concentrations, and uptake rates by benthic algae (Stelzer \& Lamberti, 2001; Snyder et al., 2002). Inclusion and variability in detritus, bacteria, and meiofauna may affect use of $\mathrm{N}: \mathrm{P}$ ratios in periphyton samples to estimate algal $\mathrm{N}: \mathrm{P}$ ratios in field studies.

Low average N:P ratios in periphyton indicated the possibility of N-limitation of algal accrual. Average N:P ratios in periphyton were 11 and 9 in $\mathrm{KY}$ and MI, which is less than Redfield ratio and much less than the 103 and $84 \mathrm{~N}: \mathrm{P}$ ratios in $\mathrm{KY}$ and MI waters. Humphrey \& Stevenson (1992) showed molar N:P ratios decreasing from 13.4 to 3.1 during periphyton community development in experimental streams, which was hypothesized to be due to greater cellular retention and within-mat 

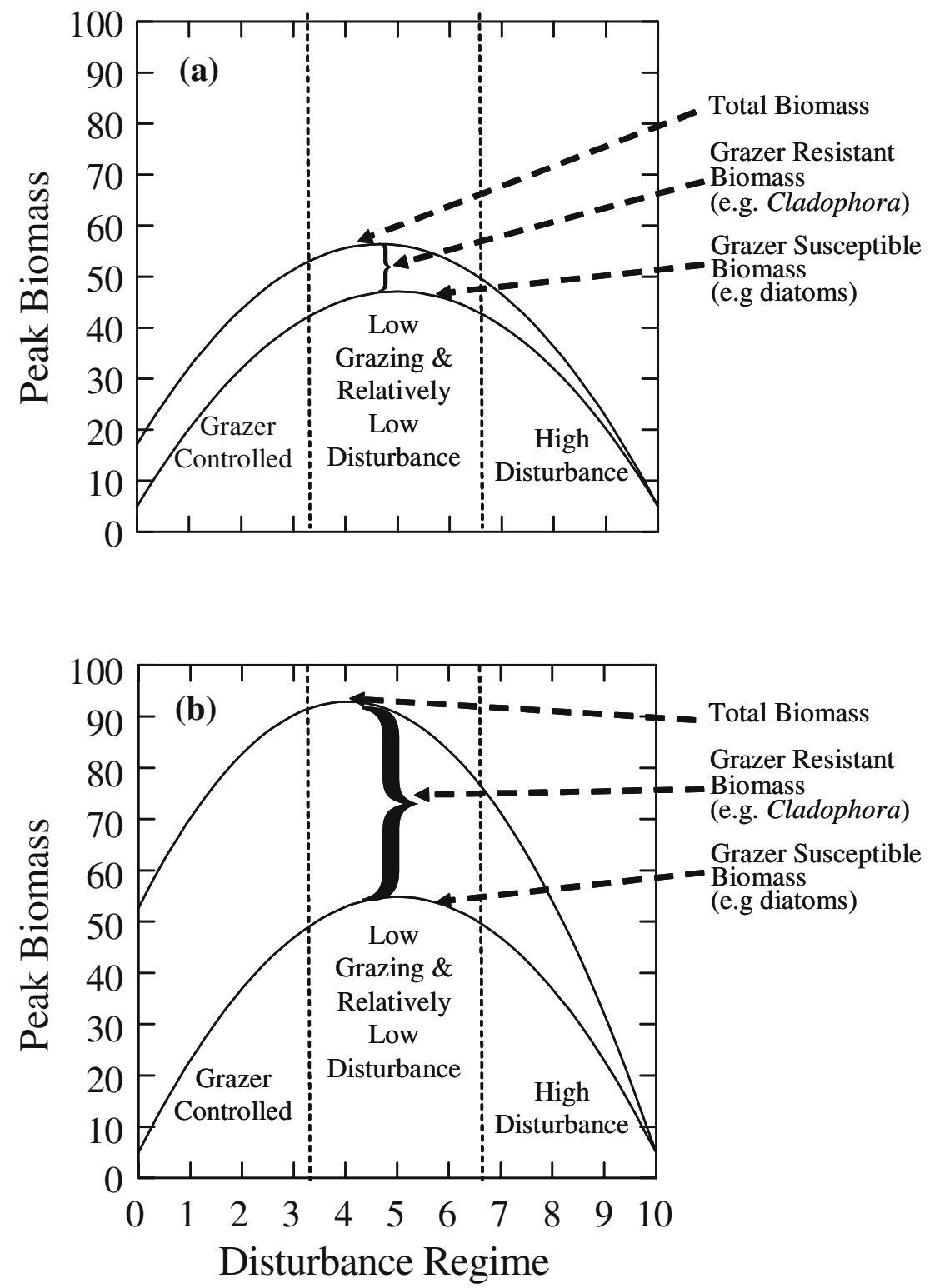

Figure 8. Conceptual model of effects of physical disturbance regime on peak biomass of grazer susceptible algae, grazer resistant algae (such as Cladophora), and all benthic algae in relatively low (a) and high (b) nutrient conditions. Grazer density is hypothesized to be high in low disturbance regimes, where grazers regulate accumulation of grazer-susceptible algae (such as diatoms). In high nutrients and low disturbance, grazers cannot regulate density of grazer resistant forms, such as Cladophora. Grazer density decreases with disturbance (Riseng et al. 2004) and enables accrual of both grazer-susceptible and resistant forms in habitats with intermediate levels of disturbance. In high disturbance, accrual of both grazer-susceptible and grazer-resistant forms are constrained physical disturbance.

recycling of $\mathrm{P}$ than $\mathrm{N}$. Thus, initial algal accrual after disturbance may be regulated by $\mathrm{P}$ availability, but sustained accrual to reach high biomass may depend on $\mathrm{N}$ availability. In addition, $\mathrm{N}$ and $\mathrm{P}$ limitation may vary seasonally with seasonal differences in uptake and retention of nutrients by terrestrial vegetation in temperate zones (Meyer et al., 1988). Criteria for $\mathrm{N}$ as well as $\mathrm{P}$ may be useful for constraining accumulations of nuisance algal growths.

We did not find thresholds in algal biomass-nutrient relations, which can be predicted 
based on models and can be helpful in establishing criteria for protecting valued ecological attributes (Stevenson, 1997a; Muradian, 2001; Stevenson et al., in press). We found some evidence of diatoms and Cladophora escaping from grazing pressure in high nutrient concentrations in the glaciated MI region, but little evidence of saturating nutrient concentrations at high $\mathrm{N}$ and $\mathrm{P}$ levels. The great spatial and temporal variability in measures of algal biomass and nutrient availability may have masked non-linear relationships between biomass and nutrients. In addition, saturation of algal growth by $\mathrm{N}$ and $\mathrm{P}$ at high concentrations may be complicated by the increasing nutrient demand that likely results as biomass increases and constrains nutrient transport and availability (Stevenson \& Glover, 1993; Rier \& Stevenson, accepted).

Without threshold responses in algal-nutrient relationships, we need to rely more on the reference approach for criteria development (Hughes \& Larsen, 1986; Hughes, 1995). Streams in both MI and KY with the lowest levels of human disturbance in watersheds (reference streams, $n=6$ ) had TP $\leq 11 \mu \mathrm{g}^{-1}$ and TN $\leq 400 \mu \mathrm{g} \mathrm{l}^{-1}$. Nutrient concentrations in our study streams increased with $\%$ agriculture and decreased with $\%$ forest in both regions (Riseng et al., 2004; Wang \& Stevenson, accepted). Given our observed probability of Cladophora cover in low nutrient, reference streams, Cladophora accrual would be very low in the most natural streams. Streams with low nutrient conditions in the EMAP study of the Mid-Atlantic region (unpublished data) also had very little occurrence of filamentous algae. In MI, diatom rank was constrained to 0.5 in reference streams, which corresponded to a chl $a$ concentration of $\approx 1.0 \mu \mathrm{g} \mathrm{cm}^{-2}$; but a wider range of diatom ranks were observed in KY. Figure 5 indicates benthic chl $a$ would be about 1 and $2 \mu \mathrm{g} \mathrm{cm}^{-2}$ in reference streams of MI and KY, respectively, which is very similar to the definition of oligotrophic streams by Dodds et al. (1998). However, the TP and TN concentrations in our reference streams are about half of the concentrations recommended by Dodds et al. (1998) as the oligotrophic-mesotrophic boundary.

High algal biomasses, for example average Cladophora cover $>20 \%$ or $>40 \%$ maximum cover were rare (less than $10 \%$ of streams) in both regions, if TP was less than $30 \mu \mathrm{g} 1^{-1}$ and $\mathrm{TN}$ was less than $1000 \mu \mathrm{g}^{-1}$. The $30 \mu \mathrm{g} \mathrm{TP} 1^{-1}$ target was also recognized by Dodds et al. (1998) as a concentration that constrained chl $a$ to less than $15 \mu \mathrm{g}$ chl $a \mathrm{~cm}^{-2}$ in a Cladophora dominated stream. Higher probabilities of more extensive Cladophora growths were observed with increasing nutrient levels. Thus, $30 \mu \mathrm{g} \mathrm{TP} 1^{-1}$ and $1000 \mu \mathrm{g} \mathrm{TN} 1^{-1}$ could be considered as targets to prevent a high probability of nuisance accrual of Cladophora.

Thus, different nutrient criteria could be established to support stream-specific management goals. The concept of "tiered aquatic life uses" has been suggested to enable protection of high quality waters as well as goals for restoring impaired ecosystems (S.B. Davies \& S.K. Jackson, submitted). To protect naturally low levels of productivity and algal biomass in streams that are hydrogeomorphically similar to our study streams, nutrient concentrations should probably be constrained to $\leq 10 \mu \mathrm{g} \mathrm{TP} 1^{-1}$ and $400 \mu \mathrm{g} \mathrm{TN} 1^{-1}$. To prevent nuisance growths of Cladophora, higher criteria in the range of $30 \mu \mathrm{g} \mathrm{TP} 1^{-1}$ and $1000 \mu \mathrm{g}$ $\mathrm{TN}^{-1}$ may be satisfactory. More research is necessary to refine these criteria, but these concentrations should provide a starting point for adaptive management of nutrients in streams.

In conclusion, relationships between algal biomass and nutrient concentrations in streams varied with the type of algae and the region. Epilithic diatom biomass did not respond as much to nutrient enrichment as Cladophora cover. Some evidence suggested $\mathrm{N}$ as well as $\mathrm{P}$ limitation of high biomass accrual. Different $\mathrm{P}$ and $\mathrm{N}$ criteria can be identified to support high quality conditions in selected streams and to restore minimum acceptable levels of biological condition. Further refinement of algal-nutrient relationships is warranted to relate algal problems to $\mathrm{N}$ as well as $\mathrm{P}$ and to other valued ecological attributes, such as taste and odor in drinking water, low DO, and impaired habitat for invertebrates and fish.

\section{Acknowledgements}

This research was sponsored by the EPA-STAR Water and Watersheds Program, Grant number R824783. Joe Holomuzki provided assistance in the field and with ideas about study design. Laurel 
Nida, Carrie DeJaco, and Jennifer Slate helped with field work. Brian Wade provided additional laboratory assistance. Yangdong Pan, Alan Steinman, and people working in Stevenson's lab provided valuable reviews of the paper.

\section{References}

APHA, 1998. Standard Methods for the Evaluation of Water and Wastewater, 20th edn. American Public Health Association, Washington, DC.

Biggs, B. J. F., 1995. The contribution of flood disturbance, catchment geology and land use to the habitat template of periphyton in stream ecosystems. Freshwater Biology 33: 419-438.

Biggs, B. J. F., 2000. Eutrophication of streams and rivers: dissolved nutrient-chlorophyll relationships for benthic algae. Journal of the North American Benthological Society 19: 17-31.

Biggs, B. J. F., M. J. Duncan, I. G. Jowett, J. M. Quinn, C. W. Hickey, R. J. Davies-Colley \& M. E. Close, 1990. Ecological characterisation, classification, and modeling of New Zealand rivers: an introduction and synthesis. New Zealand Journal of Marine and Freshwater Research 24: 277-304

Biggs, B. J. F. \& H. A. Thomsen, 1995. Disturbance of stream periphyton by perturbations in shear stress: time to structural failure and differences in community resistance. Journal of Phycology 31: 233-241.

Biggs, B. J. F., R. J. Stevenson \& R. L. Lowe, 1998. A habitat matrix conceptual model for stream periphyton. Archiv für Hydrobiologie 143: 21-56.

Blum, J. L., 1957. An ecological study of the algae of the Saline River, Michigan. Hydrobiologia 9: 361-408.

Bothwell, M. L., 1989. Phosphorus-limited growth dynamics of lotic periphytic diatom communities: areal biomass and cellular growth rate responses. Canadian Journal of Fisheries and Aquatic Sciences 46: 1293-1301.

Bourassa, N. \& A. Cattaneo, 1998. Control of periphyton biomass in Laurentian streams (Quebec). Journal of the North American Benthological Society 17: 420-429.

Burroughs, W. G., 1926. The Geography of the Kentucky Knobs. The Kentucky Geological Survey, Frankfort, Kentucky.

Carpenter, S. R., N. F. Caraco, D. L. Correll, R. W. Howarth, A. N. Sharpley \& V. H. Smith, 1998. Nonpoint pollution of surface waters with phosphorus and nitrogen. Ecological Applications 8: 559-568.

Chetelat, J., F. R. Pick, A. Morin \& P. B. Hamilton, 1999. Periphyton biomass and community composition in rivers of different nutrient status. Canadian Journal of Fisheries and Aquatic Sciences 56: 560-569.

Clausen, B. \& B. J. F. Biggs, 1997. Relationships between benthic biota and hydrological indices in New Zealand streams. Freshwater Biology 38: 327-342.

Cobb, D. G., T. D. Galloway \& J. F. Flannagan, 1992. Effects of discharge and substrate stability on density and species composition of stream insects. Canadian Journal of Fisheries and Aquatic Sciences 49: 1788-1795.

Davies, S. B. \& S. K. Jackson, submitted. The biological condition gradient: a conceptual model for interpreting detrimental change in aquatic ecosystems. Ecological Applications.

D'Elia, C. F., J. A. Steudler \& N. Corwin, 1977. Determination of total nitrogen in aqueous samples using persulfate digestion. Limnology and Oceanography 22: 760-764.

Dodds, W. K., 1991. Micro-environmental characteristics of filamentous algal communities of flowing freshwaters. Freshwater Biology 25: 199-209.

Dodds, W. K., 2003. Misuse of inorganic N and soluble reactive $\mathrm{P}$ concentrations to indicate nutrient status of surface waters. Journal of the North American Benthological Society 22: $171-181$.

Dodds, W. K. \& D. A. Gudder, 1992. The ecology of Cladophora. Journal of Phycology 28: 415-427.

Dodds, W. K., J. R. Jones \& E. B. Welch, 1998. Suggested criteria for stream trophic state: distributions of temperate stream types by chlorophyll, total nitrogen and phosphorus. Water Research 32: 1455-1462.

Dodds, W. K., V. H. Smith \& K. Lohman, 2002. Nitrogen and phosphorus relationships to benthic algal biomass in temperate streams. Canadian Journal of Fisheries and Aquatic Sciences 59: 865-874.

Dudley, T. L., S. D. Cooper \& N. Hemphill, 1986. Effects of macroalgae on a stream invertebrate community. Journal of the North American Benthological Society 5: 93-106.

Dudley, T. L. \& C. M. D'Antonio, 1991. The effects of substrate texture, grazing, and disturbance on macroalgal establishment in streams. Ecology 72: 297-309.

Feminella, J. W. \& C. P. Hawkins, 1995. Interactions between stream herbivores and periphyton: a quantitative analysis of past experiments. Journal of the North American Benthological Society 14: 465-509.

Fisher, S. G., L. J. Gray, N. B. Grimm \& D. E. Bush, 1982. Temporal succession in a desert stream ecosystem following flash flooding. Ecological Monographs 52: 93-110.

Francoeur, S. N., 2001. Meta-analysis of lotic nutrient amendment experiments: detecting and quantifying subtle responses. Journal of North American Benthological Society 20: $358-368$

Gordon, N. D., T. A. McMahon \& B.L. Finlayson, 1995. Stream Hydrology: An Introduction for Ecologists. John Wiley and Sons, Inc, New York.

Hughes, R. M., 1995. Defining acceptable biological status by comparing with reference conditions. In Davis, W. S. \& T. P. Simon (eds), Biological Assessment and Criteria: Tools for Water Resource Planning and Decision Making. Lewis Publishers, Boca Raton, Florida, USA: 31-47.

Hughes, R. M. \& D. P. Larsen, 1986. Regional reference sites: a method for assessing stream potentials. J. M. Omernik Environmental Management 10: 629-635.

Humphrey, K. P. \& R. J. Stevenson, 1992. Responses of benthic algae to pulses in current and nutrients during simulations of subscouring spates. Journal of the North American Benthological Society 11: 37-48. 
Hynes, H. B. N., 1970. The Ecology of Running Waters. University of Toronto Press, Toronto.

Kim, B. K. A., A. P. Jackman \& F. J. Triska, 1992. Modeling biotic uptake by periphyton and transient hyporrheic storage of nitrate in a natural stream. Water Resources Research 28: 2743-2752.

Kohler, S. L. \& M. J. Wiley, 1997. Pathogen outbreaks reveal large-scale effects of competition in stream communities. Ecology 87: 2164-2176.

Lamberti, G. \& V. H. Resh, 1983. Stream periphyton and insect herbivores: an experimental study of grazing by a caddisfly population. Ecology 64(5): 1124-1135.

McGrain, P., 1983. The Geologic Story of Kentucky. Kentucky Geological Survey. University of Kentucky, Lexington, Kentucky.

Meyer, J. L., W. H. McDowell, T. L. Bott, J. W. Elwood, C. Ishizaki, J. M. Melack, B. L. Peckarsky, B. J. Peterson \& P. A. Rublee, 1988. Elemental dynamics in streams. Journal of the North American Benthological Society 7: 410-432.

Muradian, R., 2001. Ecological thresholds: a survey. Ecological Economics 38: 7-24.

Poff, N. L. \& J. V. Ward, 1989. Implications of streamflow variability and predictability for lotic community structure: a regional analysis of streamflow patterns. Canadian Journal of Fisheries and Aquatic Sciences 46: 1805-1818.

Power, M. E. \& A. J. Stewart, 1987. Disturbance and recovery of an algal assemblage following flooding in an Oklahoma stream. American Midland Naturalist 117: 333-345.

Rier, S. T. \& R. J. Stevenson, 2006. Response of periphytic algae to gradients in nitrogen and phosphorus in streamside mesocosms. Hydrobiologia 561: 131-147.

Riseng, C. M., M. J. Wiley \& R. J. Stevenson, 2004. Hydrologic disturbance and nutrient effects on the structure of benthic communities in Midwestern streams: a covariance structure analysis. Journal of the North American Benthological Society 23: 309-326.

Smith, V. H., G. D. Tilman \& J. C. Nekola, 1999. Eutrophication: impacts of excess nutrient inputs on freshwater, marine, and terrestrial ecosystems. Environmental pollution 100: 179-196.

Snyder, E. B., C. T. Robinson, G. W. Minshall \& S. R. Rushforth, 2002. Regional patterns in periphyton accrual and diatom assemblage structure in a heterogeneous nutrient landscape. Canadian Journal of Fisheries and Aquatic Science 59: 564-577.

Stelzer, R. S. \& G. A. Lamberti, 2001. Effects of N:P ratio and total nutrient concentration on stream periphyton community structure, biomass, and elemental composition. Limnology and Oceanography 46: 356-367.
Stevenson, R. J., 1997a. Resource thresholds and stream ecosystem sustainability. Journal of the North American Benthological Society 16: 410-424.

Stevenson, R. J., 1997b. Scale-dependent determinants and consequences of benthic algal heterogeneity. Journal of North American Benthological Society 16: 248-262.

Stevenson, R. J., C. G. Peterson, D. B. Kirschtel, C. C. King \& N. C. Tuchman, 1991. Density-dependent growth, ecological strategies, and effects of nutrients and shading on benthic diatom succession in streams. Journal of Phycology 27: 59-69.

Stevenson, R. J. \& R. Glover, 1993. Effects of algal density and current on ion transport through periphyton communities. Limnology \& Oceanography 38: 1276-1281.

Stevenson, R. J., Y. Pan \& P. Vaithiyanathan, 2002. Ecological assessment and indicator development in wetlands: the case of algae in the Everglades, USA. Verhandlungen Internationale Vereinigung für Theoretische und Andgewandte Limnologie 28: 1248-1252.

Stevenson, R. J., J. Alba-Tercedor, B. Bailey, M. Barbour, C. Couch, S. Dyer, F. Fulk, J. Harrington, M. Harass, C. J. Hawkins, C. Hunsaker, R. Johnson \& K. Thornton. in press. Interpreting results of ecological assessments. In Barbour, M., K. Thornton, R. Preston \& S. Norton (eds), Ecological Assessment of Aquatic Resources: Linking Science to Decision-Making. Society of Environmental Toxicology and Contamination Publication.

Strahler, A. N., 1952. Hyposometric (area-altitude) analysis of erosional topography. Bulletin of the Geological Society of America 63: 1117-1142.

USEPA, 1999. Nutrient Criteria Technical Guidance Manual: Rivers and Streams. EPA-822-D-99-003. United States Environmental Protection Agency, Washington, D.C.

Wang, Y. K., R. J. Stevenson \& L. Metzmeier, 2005. Development and evaluation of a diatom-based index of biotic integrity for the Interior Plateau Ecoregion. Journal of the North American Benthological Society 24: 990-1008.

Wiley, M. J., S. L. Kohler \& P. W. Seelbach, 1997. Reconciling landscape and local views of aquatic communities: lessons from Michigan trout streams. Freshwater Biology 37: 133-148.

Wilkinson, L., 1990. SYSTAT: The System for Statistics. SYSTAT, Inc, Evanston, IL.

Wootton, J. T., M. S. Parker \& M. E. Power, 1996. Effects of disturbance on river food webs. Science 273: 1558-1561.

Zar, J. H., 1974. Biostatistical Analysis. Prentice-Hall, Inc, Edgewood Cliffs, NJ. 